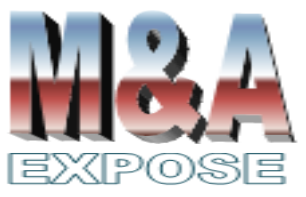

http://jurnal.usahid.ac.id/index .php/accounting
1,2 Fakultas Ekonomi dan Bisnis Universitas Sahid 1'dewi.anggraini20081974@g mail.com 2ihondanielthorp@gmail.com

\section{Pengaruh Pendidikan, Ukuran Usaha, dan Lama Usaha terhadap Penggunaan Informasi Akuntansi}

\author{
Dewi Anggraini ${ }^{1}$, Jhon Daniel Thorp ${ }^{2}$
}

\section{Abstrak}

Penelitian ini bertujuan untuk menganalisis pengaruh pendidikan, ukuran usaha dan lama usaha terhadap penggunaan informasi akuntansi. Metode penentuan sampel yang digunakan pada penelitian ini adalah metode Slovin sehingga diperoleh 63 sampel. Hasil penelitian menunjukkan bahwa Pendidikan, Ukuran Usaha, dan Lama Usaha secara simultan berpengaruh signifikan terhadap Penggunaan Informasi Akuntansi. Pendidikan dan lama usaha secara parsial berpengaruh signifikan terhadap Penggunaan Informasi Akuntansi. Ukuran Usaha berpengaruh tidak signifikan terhadap penggunaan Informasi Akuntansi. Nilai koefisien determinasi $\left(R^{2}\right)$ menunjukkan bahwa keseluruhan variabel independen yaitu pendidikan, ukuran usaha, dan lama usaha memiliki kontribusi secara bersama-sama sebesar $77 \%$ terhadap variabel dependen yaitu penggunaan informasi akuntansi, sedangkan sisanya dipengaruhi oleh faktor-faktor lain di luar model penelitian ini.

Kata kunci : Pendidikan, Ukuran Usaha, Lama Usaha, Penggunaan Informasi Akuntansi.

\section{Abstract}

This study aims to analyze the effect of education, business size and length of business on the use of accounting information. The sampling method used in this study is the Slovin method so that 63 samples are obtained. The results showed that Education, Business size and Length of Business simultaneously had a significant effect on the use of Accounting Information. Education and Business partially have a significant effect on the use of accounting information. Business size has no significant effect on the use of Accounting Information. The coefficient of determination $\left(R^{2}\right)$ indicated that the overall independent variable have contibuted together $77 \%$ of the dependent variable, while the remaining is influenced by other factors.

Keywords : Education, Business Size, Length Of Business, Use Of Accounting Information. 


\section{PENDAHULUAN}

Suatu perusahaan sangat membutuhkan informasi akuntansi dalam rangka mengetahui kondisi keuangan perusahaan seperti informasi tentang pembelian, penjualan, beban yang dikeluarkan, hutang dan piutang perusahaan, persediaan barang dagang, laba rugi yang diperoleh, serta informasi tentang arus kas perusahaan. Tidak hanya perusahaan skala besar yang membutuhkan informasi akuntansi, perusahaan kecil, mikro dan menengah juga perlu mengetahui bagaimana posisi keuangan perusahaan, bagaimana kinerja perusahaan, sehingga bisa diketahui apakah usaha yang dijalankan berkembang atau tidak. Menurut Ikatan Akuntan Indonesia (2019) informasi akuntansi keuangan digunakan baik oleh pihak manajemen perusahaan maupun pihak eksternal perusahaan dengan tujuan untuk menyediakan informasi yang menyangkut posisi keuangan, kinerja serta perubahan keuangan perusahaan yang bermanfaat bagi sejumlah besar pemakai dalam pengambilan suatu keputusan.

Walaupun pembuatan informasi akuntansi sangatlah penting bagi suatu usaha, tetapi masih banyak pelaku usaha baik usaha dagang berskala mikro, kecil, atau menengah yang mesih belum membuat informasi akuntansi. Bahkan banyak pula pelaku usaha kecil baik usaha dagang atau Usaha Mikro, Kecil, dan Menengah (UMKM) yang belum mengerti tentang akuntansi. Menurut Handayani (2011) kelemahan tersebut antara lain disebabkan oleh faktorfaktor seperti masa memimpin perusahaan, pendidikan pemilik, umur perusahaan dan pelatihan akuntansi yang diikuti

Salah satu usaha dagang atau UMKM yang membutuhkan akuntansi adalah usaha pertokoan. Akuntansi yang diperlukan pada usaha pertokoan meliputi pencatatan dan pelaporan keuangan. Melalui pencatatan dan pelaporan keuangan dapat mengetahui posisi usahanya, jumlah piutang, hutang, persediaan, penjualan, dan laba tiap periode. Pencatatan dan pelaporan keuangan sangat berguna untuk proses pengambilan keputusan suatu bisnis untuk melanjutkan usaha mereka.

Menurut penelitian Holmes dan Nicholls (1989) skala usaha memiliki hubungan yang positif terhadap penggunaan informasi akuntansi dengan indikator jumlah pendapatan dan jumlah karyawan. Menurut Holmes dan Nicholls (1989), skala usaha merupakan kemampuan perusahaan dalam mengelola usahanya dengan melihat berapa jumlah karyawan yang dipekerjakan dan berapa besar pendapatan yang diperoleh perusahaan dalam satu periode akuntansi. Umur perusahaan memiliki pengaruh positif terhadap tingkat penggunaan informasi akuntansi. Dalam penelitiannya, Nicholls dan Holmes menyatakan perusahaan yang memiliki usia kurang dari sepuluh tahun lebih banyak menyediakan informasi akuntansi statutori, informasi akuntansi anggaran, dan informasi tambahan yang digunakan untuk pengambilan suatu keputusan. Sedangkan untuk variable pendidikan khususnya pendidikan manajer atau pemilik memiliki peran penting dalam penggunaan informasi akuntansi, karena kemampuan atau pendidikan pemilik mempengaruhi pelaksanaan teknis akuntansi dalam usaha tersebut.

Merujuk pada penelitian yang dilakukan oleh Holmes dan Nichols (1989) peneliti menggunakan variable pendidikan, ukuran usaha, dan lama usaha. Perbedaan dengan penelitian Holmes dan Nichols (1989) yang menggunakan variable skala usaha, umur perusahaan, sektor industri dan pendidikan manajer/pemilik perusahaan dalam penelitiannya, penulis tidak menggunakan variabel sektor industri. 
Tujuan dari penelitian ini adalah untuk mengetahui apakah pendidikan, ukuran usaha dan lama usaha secara simultan maupun secara parsial berpengaruh signifikan terhadap penggunaan informasi akuntansi.

\section{TINJAUAN PUSTAKA}

Menurut Belkaoui (2006), informasi akuntansi adalah informasi kuantitatif tentang entitas ekonomi yang bermanfaat untuk pengambilan keputusan ekonomi dalam menentukan pilihan-pilihan di antara alternatif tindakan. Penggunaan informasi akuntansi itu untuk perencanaan strategis, pengawasan manajemen, dan pengawasan operasional. Menurut Holmes dan Nicholls (1989) kekurangan informasi akuntansi dalam manajemen perusahaan dapat membahayakan operasional perusahaan. Kekurangan catatan akuntansi dapat membatasi akses untuk memperoleh informasi yang diperlukan untuk membuat kebijakankebijakan penting perusahaan sehingga dapat menyebabkan kebangkrutan pada perusahaan. Oleh sebab itu, penggunaan informasi akuntansi berpengaruh besar dalam perencanaan dan pengendalian perusahaan.

Menurut Ihsan (2011), tingkat atau jenjang pendidikan adalah tahap pendidikan yang berkelanjutan, yang ditetapkan berdasarkan tingkat perkembangan peserta didik, tingkat kerumitan bahan pengajaran, dan cara menyajikan bahan pengajaran. Penelitian Novianti (2018), Anjani (2018), Nirwana (2019) memperlihatkan bahwa pendidikan berpengaruh terhadap penggunaan informasi akuntansi.

Menurut Suwito dan Herawaty (2005), ukuran perusahaan pada dasarnya adalah pengelompokan perusahaan ke dalam beberapa kelompok, di antaranya perusahaan besar, sedang dan kecil. Skala perusahaan merupakan ukuran yang dipakai untuk mencerminkan besar kecilnya perusahaan yang didasarkan kepada total aset perusahaan. Hasil penelitian Nahar dan Widiastuti (2011), Nurhayati (2015), Novianti (2018), Nirwana (2019) menyatakan ukuran perusahaan berpengaruh terhadap penggunaan informasi akuntansi. Menurut Seftianne (2011) ukuran perusahaan adalah skala perusahaan yang dilihat dari total aktiva perusahaan pada akhir tahun. Total penjualan juga dapat digunakan untuk mengukur besarnya perusahaan. Menurut Veronica dan Siddharta (2005), ukuran perusahaan menggambarkan besar kecilnya perusahaan. Besar kecilnya usaha tersebut ditinjau dari lapangan usaha yang dijalankan. Penentuan skala besar kecilnya perusahaan dapat ditentukan berdasarkan total penjualan, total aset, dan rata-rata tingkat penjualan.

Menurut Asmie (2018), lama usaha merupakan lamanya pedagang berkarya pada usaha perdagangan yang sedang dijalani saat ini. Secara harfiah jika suatu usaha sudah berjalan cukup lama maka akan mengalami berbagai perubahan di berbagai aspek usaha. Perubahan ini disebabkan karena adanya pengetahuan-pengetahuan yang didapat selama menjalani usaha seperti mulai menetapkan sistem dan metode informasi akuntansi, metode pemasaran, metode pengolahan modal, dan lain-lain. Dari hasil penelitian Nirwana (2019), Dewi (2018) menunjukkan bahwa lama usaha berpengaruh terhadap penggunaan informasi akuntansi

Berdasarkan permasalahan penelitian dan tinjauan pustaka, maka dapat dirumuskan hipotesis penelitian ini adalah sebagai berikut:

$\mathrm{H} 1$ : Pendidikan, ukuran usaha, dan lama usaha secara simultan berpengaruh signifikan terhadap penggunaan informasi akuntansi. 
H2 : Pendidikan berpengaruh signifikan terhadap penggunaan informasi akuntansi.

H3 : Ukuran usaha berpengaruh signifikan terhadap penggunaan informasi akuntansi.

H4 : Lama usaha berpengaruh signifikan terhadap penggunaan informasi akuntansi.

\section{METODE PENELITIAN}

Penelitian ini dilakukan di kawasan Pusat Grosir Cililitan yang banyak terdapat berbagai jenis usaha dagang. Dari berbagai usaha dagang yang banyak terdapat di Pusat Grosir Cililitan, salah satu yang cukup digemari oleh masyarakat saat ini adalah usaha dagang handphone. Populasi penelitian ini adalah pemilik gerai handphone yang berjualan di Pusat Grosir Cililitan, Jakarta Timur sebanyak 75 toko. Karakteristik sampel dalam penelitian ini adalah para pemilik gerai handphone yang berjualan di area lantai 3 Pusat Grosir Cililitan, Jakarta Timur yang umur usahanya minimal satu tahun dan sudah membuat informasi akuntansi. Metode penentuan sampel yang digunakan pada penelitian ini adalah Metode Slovin sehingga didapatkan jumlah sampel sebanyak 63.

Data yang digunakan dalam penelitian ini yakni data primer. Data primer dalam penelitian ini diperoleh dari penyebaran kuesioner secara langsung kepada responden. Kuesioner dikirimkan secara langsung kepada responden melalui personal chat berupa link google form dan menyebar formulir kuesioner secara langsung. Jangka waktu yang ditentukan dalam pengisian kuesioner ini, yaitu 7-10 hari setelah kegiatan penyebaran kuesioner dilakukan.

Variabel dependen dalam penelitian ini adalah Penggunaan Informasi Akuntansi. Variabel Penggunaan Informasi Akuntansi diukur menggunakan skala Likert dengan lima pilihan skala.

Variabel independen dalam penelitian ini adalah Pendidikan, Ukuran Usaha, dan Lama Usaha. Indikator dari variabel Pendidikan adalah pendidikan formal yang telah atau sedang ditempuh oleh pemilik gerai handphone. Menurut Grace (2003) dan Fitriyah (2006), pendidikan formal adalah pendidikan yang diperoleh dibangku sekolah formal antara lain sekolah dasar (SD), sekolah menengah pertama (SMP), sekolah menengah umum (SMU), diploma, sarjana dan pascasarjana. Skala usaha dalam penelitian ini didasarkan pada jumlah tenaga kerja full time yang bekerja di gerai handphone, jumlah aset pemilik gerai, dan pendapatan pertahun gerai handphone. Lama usaha dalam penelitian ini didasarkan pada lama atau umur usaha gerai handphone.

Untuk melihat apakah variabel pendidikan, ukuran usaha, dan lama usaha pemilik gerai handphone terhadap penggunaan informasi akuntansi digunakan analisis regresi linier berganda sebagai berikut :

$$
\begin{array}{ll}
\mathrm{Y}=\mathrm{a}+\mathrm{b}_{1} \mathrm{X}_{1}+\mathrm{b}_{2} \mathrm{X}_{2}+\mathrm{b}_{3} \mathrm{X}_{3}+\mathrm{e} \\
\mathrm{Y} & : \text { Penggunaan Informasi Akuntansi } \\
\mathrm{X}_{1} & : \text { Pendidikan } \\
\mathrm{X}_{2} & : \text { Ukuran Usaha } \\
\mathrm{X}_{3} & : \text { Lama Usaha } \\
\mathrm{e} & : \text { Error } \\
\mathrm{b} & : \text { Konstanta }
\end{array}
$$


Untuk menganalisis pengaruh signifikan variabel independen terhadap variabel dependen digunakan Uji Simultan atau Uji F dengan tingkat signifikansi 0.05 atau 5 persen. Adapun untuk menganalisis pengaruh signifikan variabel independen terhadap variabel dependen secara parsial digunakan uji t dengan tingkat signifikansi $(\alpha) 0.05$ atau $\alpha=5$ persen. Selanjutnya untuk menganalisis seberapa besar kemampuan variabel independen/bebas dapat menerangkan variabel dependen/terikat dilakukan dengan pengujian koefisien determinasi $\left(R^{2}\right)$.

\section{HASIL DAN PEMBAHASAN}

Sebelum melakukan pengujian hipotesis, terlebih dahulu dilakukan uji asumsi klasik. Tujuannya adalah untuk memberikan kepastian bahwa persamaan regresi yang didapatkan memiliki ketepatan dalam estimasi, tidak bias dan konsisten. Berdasarkan hasil analisis deskriptif, untuk tingkat pendidikan memiliki nilai minimum 4 dan maksimum 7. Ukuran usaha memiliki nilai minimum sebesar 5 dan maksimum 12. Sedangkan lama usaha memiliki nilai minimum 1 dan maksimum 4.

Dalam penelitian ini, diperoleh hasil dari uji regresi linear berganda seperti pada tabel di bawah ini:

Tabel 1. Analisis Regresi Berganda

\begin{tabular}{llll}
\hline \multicolumn{1}{c}{ Model } & \multicolumn{2}{c}{$\begin{array}{c}\text { Unstandardized } \\
\text { Coefficiens }\end{array}$} & $\begin{array}{c}\text { Standardized } \\
\text { Coefficiens }\end{array}$ \\
\hline & $\mathrm{B}$ & Std. Error & Beta \\
\hline (Constant) & 10,821 & 3,881 & \\
Pendidikan & 5,789 & 0,570 & 0.688 \\
Ukuran Usaha & 0,208 & 0,436 & 0.036 \\
Lama Usaha & 3,908 & 0,935 & 0.317 \\
\hline Dependent : Penggunaan Informasi Akuntansi & \\
Sumber : Data diolah & &
\end{tabular}

Sesuai tabel diatas, persamaan regresi adalah sebagai berikut:

$$
Y=10,821+5,789 X_{1}+0,208 X_{2}+3,908 X_{3}+e
$$

Berdasarkan persamaan regresi di atas, dapat diuraikan bahwa nilai konstanta adalah sebesar 10,821, hal ini menunjukan bila Pendidikan, Ukuran Usaha, dan Lama Usaha minim sekalipun, Penggunaan Informasi Akuntansi tetap ada. Koefisien pendidikan sebesar 5,789, hal ini menunjukan bahwa setiap penambahan faktor Pendidikan sebesar satu satuan, maka akan meningkatkan Penggunaan Informasi Akuntansi sebesar 5,789, dengan asumsi variabel independen lain nilainya tetap. Koefisien ukuran usaha sebesar 0,208, hal ini menunjukan bahwa setiap penambahan faktor Ukuran Usaha sebesar satu satuan, maka akan meningkatkan Penggunaan Informasi Akuntansi sebesar 0,208, dengan asumsi variabel independen lain nilainya tetap. Koefisien lama usaha sebesar 3,908, hal ini menunjukan bahwa setiap penambahan faktor Lama Usaha sebesar satu satuan, maka akan meningkatkan Penggunaan Informasi Akuntansi sebesar 3,908, dengan asumsi variabel independen lain nilainya tetap. 
Dalam penelitian ini, diperoleh hasil dari uji simultan atau uji $\mathrm{F}$ seperti pada tabel dibawah ini:

Tabel 2. Uji F

\begin{tabular}{lllllc}
\hline \multicolumn{1}{c}{ Model } & $\begin{array}{c}\text { Sum of } \\
\text { Squares }\end{array}$ & df & $\begin{array}{c}\text { Mean } \\
\text { Square }\end{array}$ & $F$ & Sig \\
\hline Regression & $2.576,157$ & 3 & 858,719 & 70,352 & 0,000 \\
Residual & 720,160 & 59 & 12,206 & & \\
Total & $3.296,317$ & 62 & & \\
\hline
\end{tabular}

Dari tabel di atas dapat dilihat bahwa nilai sig sebesar 0,00 adalah lebih kecil dari 0,05 yang berarti bahwa secara simultan pendidikan, ukuran usaha dan lama usaha berpengaruh signifikan terhadap penggunaan informasi akuntansi.

Dalam penelitian ini, diperoleh hasil dari uji parsial atau uji t seperti pada tabel di bawah ini :

Tabel 3. Uji t

\begin{tabular}{lllll}
\hline Variabel & $\mathrm{B}$ & $\mathrm{t}$ hitung & $\mathrm{t}$ tabel & Sig \\
\hline Constant & 10,821 & 2,788 & & 0,007 \\
Pendidikan & 5,789 & 10,162 & 1,671 & 0,000 \\
Ukuran Usaha & 0,208 & 0,478 & 1,671 & 0,635 \\
Lama Usaha & 3,908 & 4,180 & 1,671 & 0,000 \\
\hline
\end{tabular}

Sumber : data diolah

Berdasarkan tabel di atas dapat dilihat bahwa nilai signifikan Pendidikan adalah sebesar 0,000 yaitu lebih kecil dari 0,05 sehingga dapat disimpulkan bahwa Pendidikan berpengaruh signifikan terhadap Penggunaan Informasi Akuntansi. Untuk ukuran usaha mempunyai nilai signifikan sebesar 0,635 yaitu lebih besar dari 0,05 yang berarti bahwa ukuran usaha tidak berpengaruh terhadap penggunaan informasi akuntansi. Sedangkan lama usaha mempunyai nilai signifikan sebesar 0,000 yaitu lebih kecil dari 0,05 yang berarti bahwa lama usaha berpengaruh signifikan terhadap penggunaan informasi akuntansi.

Dalam penelitian ini, diperoleh hasil uji Koefisien Determinasi $\left(R^{2}\right)$ seperti pada tabel dibawah ini:

Tabel 4. Koefisien Determinasi $\left(\mathrm{R}^{2}\right)$

\begin{tabular}{lllll}
\hline Model & $\mathrm{R}$ & $\mathrm{R}$ Square & $\begin{array}{c}\text { Adjusted R } \\
\text { Square }\end{array}$ & $\begin{array}{c}\text { Std. Error of the } \\
\text { Estimate }\end{array}$ \\
\hline 1 & 0,884 & 0,782 & 0,770 & 3,494 \\
\hline Predictors : (Constant), Pendidikan Ukuran Usaha, Lama Usaha \\
\hline
\end{tabular}

Sesuai dengan tabel di atas dapat kita ketahui bahwa nilai adjusted $R$ Square sebesar 0,770. Hal ini berarti bahwa keseluruhan variabel independen yaitu pendidikan, ukuran usaha, dan lama usaha memiliki kontribusi secara bersama-sama sebesar 77 persen terhadap variabel dependen yaitu penggunaan informasi akuntansi. Sedangkan sisanya yaitu 23 persen 
dipengaruhi oleh faktor lain. Hal ini bermakna ketiga variabel independen berkontribusi kuat dalam menjelaskan penggunaan informasi akuntansi dalam studi kasus ini.

\section{KESIMPULAN}

Berdasarkan penelitian yang telah dilakukan maka kesimpulan dari hasil penelitian ini adalah Pendidikan, Ukuran Usaha, dan Lama Usaha secara simultan berpengaruh signifikan terhadap Penggunaan Informasi Akuntansi. Secara parsial Pendidikan dan Lama Usaha berpengaruh signifikan terhadap Penggunaan Informasi Akuntansi, namun Ukuran Usaha tidak berpengaruh terhadap penggunaan Informasi Akuntansi. Ketiga variabel independen berkontribusi kuat dalam menjelaskan penggunaan informasi akuntansi dalam studi kasus ini.

\section{DAFTAR PUSTAKA}

Anjani, W. P. (2018). Pengaruh Usia, Pengalaman Kerja, Tingkat Pendidikan dan Kompleksitas Tugas Terhadap Efektifitas Penggunaan Sistem Informasi Akuntansi. EJurnal Akuntansi Universitas Udayana, 22(3).

Asmie, P. (2008). Analisis Faktor-Faktor yang Mempengaruhi Tingkat Pendapatan Pedagang Pasar Tradisional di kota Yogyakarta. Tesis. Yogayakarta: Universitas Gajah Mada.

Belkaoui, A. R., (2006). Teori Akuntansi. Edisi Pertama. Jakarta: Salemba Empat.

Dewi, K. M. (2018). Skala Usaha dan Umur Usaha Yang Mempengaruhi Penggunaan Sistem Akuntansi. Jurnal Pundi, 2(3).

Fitriyah, H. (2006). Analisis Faktor-Faktor yang Mempengaruhi Penggunaan Informasi Akuntansi pada Usaha Menengah Kabupaten Sidoarjo. Tesis. Surabaya: Program Pascasarjana Universitas Airlangga Surabaya.

Handayani, D. B. (2011). Faktor Yang Mempengaruhi Penggunaan Informasi Akuntansi Usaha Kecil dan Menengah. Jurnal Akuntabilitas. 1(1).

Holmes, S. N. (1989). An Analysis of The Use of Accounting Information By Australian Small Business. Journal of Small Business Management.

Ihsan, F. (2011). Dasar-dasar Kependidikan. Jakarta: Rineka Cipta.

Ikatan Akuntan Indonesia. (2019). Standar Akuntansi Keuangan. Efektif Per 1 Januari 2019. Jakarta: Salemba Empat.

Knutson, D. L. \& Wiehman, H. (1985). The Issues of Differential Accounting Treatment for American Small Business Management Forum.

Nahar, A, \& Widiastuti, A. (2011). Analisis Penggunaan Informasi Akuntansi Pada Industri Menengah di Kabupaten Jepara. Seminar Nasional Teknologi Informasi dan Komunikasi Terapan.

Nirwana, A. (2019). Pengaruh Jenjang Pendidikan, Skala Usaha dan Lama Usaha Terhadap Penggunaan Informasi Akuntansi Pada UMKM di Kecamatan Ciawi Gebang. Jurnal Riset Keuangan dan Akuntansi, 5(1).

Novianti, D. (2018). Pengaruh Tingkat Pendidikan, Pelatihan Akuntansi, Umur Usaha dan Skala Usaha Pelaku UMKM Terhadap Penggunaan Informasi Akuntansi di Kecamatan Purwokerto Utara. Jurnal Ekonomi, Bisnis dan Akuntansi, 20(3). 
Nurhayati, E. (2015). Pengaruh Pengetahuan Akuntansi dan Skala Usaha Terhadap Penggunaan Informasi Akuntansi Pada Usaha Kecil Menengah di Kabupaten Kuningan. Jurnal Riset Keuangan dan Akuntansi, 1(1), 29-35.

Seftianne \& Handayani. (2011). Faktor-faktor yang Mempengaruhi Struktur Modal Pada Perusahaan Publik Sektor Manufaktur. Jurnal Bisnis dan Akuntansi. 13(1), 39-56.

Suwito, E. \& Herawaty, A. (2005). Analisis Pengaruh Karakteristik Perusahaan terhadap Tindakan Perataan Laba yang dilakukan oleh Perusahaan yang Terdaftar di Bursa Efek Jakarta. Simposium Nasional Akuntansi VIII Solo.

Veronica, S. \& Utama, S. (2005). Pengaruh Struktur Kepemilikan, Ukuran Perusahaan, dan Praktek Corporate Governance terhadap Pengelolaan Laba (Earnings Management). Simposium Nasional Akuntansi VIII Solo. 